\title{
HISPIDULIN AND OTHER CONSTITUENTS OF SCOPARIA DULCIS LINN
}

\author{
D. Osei-Safo ${ }^{1}$, M.A. Chama ${ }^{1}$, I. Addae-Mensah ${ }^{1}$ and R. Waibel ${ }^{2}$ \\ ${ }^{1}$ Department of Chemistry, University of Ghana, Legon \\ ${ }^{2}$ Department of Pharmaceutical Chemistry, \\ Institute of Pharmacy and Food Chemistry, \\ University of Erlangen, 91052 Erlangen, Germany
}

\begin{abstract}
Phytochemical investigation of the ethanol extract of the whole plant of Scoparia dulcis, has resulted in the isolation of 4, 5, 7-trihydroxy-6-methoxyflavone, commonly called hispidulin and

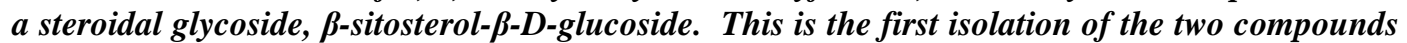
from $S$. dulcis. Also isolated and characterized were the previously reported 6-methoxybenzoxazolinone, friedelan-3-one and scopadulcic acid B. Structural elucidation was done on the basis of spectroscopic data interpretations (IR, UV, NMR and EIMS). Using the Tetrazolium-based colorimetric selective assay, hispidulin was found to be inactive against HIV-1/ IIIB in MT-4 cells whereas the same test on the aqueous extract of the plant was positive.
\end{abstract}

Keywords: Scoparia dulcis, flavones, hispidulin, $\beta$-sitosterol- $\beta$-D-glucoside, anti-HIV

\section{INTRODUCTION}

Scoparia dulcis Linn. (Scrophulariaceae) has been extensively studied for its flavone and terpene constituents (Ahmed et al., 1990, Ahsan et al., 2003, Chen et al., 1976, Hayashi et al., 1987, 1987b, 1988, 1990, 1991, 1993, Mahato et al., 1981, Nishino et al., 1993, Phan et al., 2006, Sitthithaworn et al., 2001, Taylor, 2005). A native of Central America, S. dulcis is now widely distributed in tropical America, Africa and Asia (Burkill, 2000). It has long held a place in herbal medicine in every tropical country where it grows and is still employed by the indigenous people for a variety of ailments. The main uses include pain relief, treatment for venereal diseases and chronic sores, urinary tract infections, menstrual disorders, bacterial and viral infections (Taylor, 2005). Constituents of the plant have also been demonstrated to possess analgesic (Ahmed et al., 2001, Friere et al., 1993), anti-inflammatory (Ahmed et al., 2001, Friere et al., 1993), antitumor (Hayashi et al., 1991, Nishino et al., 1993), antiviral (De Clercq, 2001, Hayashi et al., 1988, Hayashi et al., 1990, Vlietinck et al., 1998), antidiabetic (Latha et al., 2006), antimalarial (Riel et al., 2002) and antioxidant properties (Babincova et al., 2001) among others.

Most of the research work to validate the traditional use of the plant has been carried out on the Asian varieties resulting in little attention being paid to the African collections of the plant. In Ghana, the plant is exported on a large scale in its raw state to Europe and North 
America, where as a result of its versatility, extensive clinical research and syntheses of the constituents are ongoing. The present investigation is part of an attempt at value addition to the plant prior to export. We report the first-time isolation of the flavone, hispidulin and the terpene glycoside, $\beta$-sitosterol- $\beta$-D-glucoside from the plant. Anti-HIV activity of the aqueous crude extract as well as hispidulin is also reported for the first time.

\section{MATERIALS AND METHODS General}

TLC was performed on aluminium foil slides pre-coated with silica gel (thickness $0.2 \mathrm{~mm}$, type Kiesegel $60 \mathrm{~F}_{254}$ Merck); detection: UV, anisaldehyde spray reagent. Column chromatography was carried out on silica gel 60 (Fluka). Melting points (uncorrected) were determined on a Stuart Scientific Melting Point Apparatus. UV spectra were recorded on a Shimadzu UV 240 spectrophotometer. IR spectra were recorded in $\mathrm{KBr}$ discs on a Shimadzu IR408 spectrophotometer. ${ }^{1} \mathrm{H}-\mathrm{NMR}$ was run at $600 \mathrm{MHz}$ and ${ }^{13} \mathrm{C}-\mathrm{NMR}$ at $150 \mathrm{MHz}$ in $\mathrm{CDCl}_{3}$ or a mixture of $\mathrm{CD}_{3} \mathrm{COCD}_{3} / \mathrm{CD}_{3} \mathrm{OD}$ with TMS as the internal standard, on a Brüker Avance 600 Spectrophotometer. EIMS were obtained at $70 \mathrm{eV}$ using a JEOL JMS-GCMate II instrument with direct probe inlet.

\section{Plant material}

The pulverized whole plant of S. dulcis was obtained from Bioresources International (BRI) Ghana Limited in September 2003 with the code number BRI 0226.

\section{Extraction and isolation}

The air-dried pulverized plant material $(50 \mathrm{~kg})$ was percolated with 12.51 of $96 \%$ ethanol for 48 hours after which the material was exhaustively extracted with hot ethanol for 13 hours to yield $154.4 \mathrm{~g}$ of a dark green sticky solid. About $22.0 \mathrm{~g}$ of the crude extract was dissolved in a minimum amount of warm chloroform and chromatographed over silica gel eluting successively with petroleum ether, petroleum ether/ ethyl acetate mixtures and pure ethyl acetate.
The eluate was collected in $25 \mathrm{ml}$ portions and combined upon monitoring by TLC, to a total of seven fractions (A-G). Fraction A was obtained as a yellow syrup which on placing in acetone followed by recrystallization afforded $30 \mathrm{mg}$ of friedelan-3-one (Corey et al., 1956, De Mayo, 1959, Ageta, 1995). Fraction C precipitated a solid after refrigeration for a couple of days and this was recrystallized to yield scopadulcic acid B (20 mg). Rechromatography of fractions D and E gave $100 \mathrm{mg}$ of 6methoxybenzoxazolinone (Chen et al., 1976) and $250 \mathrm{mg}$ of hispidulin (1) respectively. Addition of acetone to fraction $\mathrm{G}$, followed by refrigeration, precipitated white granules which on recrystallization from $15 \%$ aqueous ethanol afforded $30 \mathrm{mg}$ of $\beta$-sitosterol- $\beta$-D-glucoside (2).

\section{Determination of the oxygenation pattern in 1 using shift reagents}

The UV spectrum of 1 was that of its $\mathrm{MeOH}$ solution. The shift reagents employed were $2 \mathrm{M}$ aqueous $\mathrm{NaOH}$ solution, $\mathrm{AlCl}_{3}$ and $\mathrm{HCl}$ from which the $\mathrm{NaOMe}, \mathrm{AlCl}_{3}$ and $\mathrm{AlCl}_{3} / \mathrm{HCl}$ spectra were obtained (Markham, 1981).

\section{Anti -HIV Test}

The Tetrazolium-based colorimetric selective assay was employed in the anti-HIV activity test of both hispidulin and the aqueous extract of the plant against HIV-1/IIIB in MT-4 cells as previously published (Ayisi et al., 1991).

\section{RESULTS AND DISCUSSION}

Compound 1, isolated as greenish yellow powder, showed an $\left[\mathrm{M}^{+}\right]$peak at $\mathrm{m} / \mathrm{z} 300(100 \%)$ corresponding to the molecular formula $\mathrm{C}_{16} \mathrm{H}_{12} \mathrm{O}_{6}$. The ${ }^{13} \mathrm{C}-\mathrm{NMR}$ spectrum, however, indicated 14 carbon resonances, implying the equivalence of two sets of carbon atoms. This was corroborated by the ${ }^{1} \mathrm{H}-\mathrm{NMR}$ spectrum where two ortho-coupled doublets $(J=9.0 \mathrm{~Hz})$ at $\delta_{\mathrm{H}} 7.82$ and $\delta_{\mathrm{H}} 6.94$, integrating for two protons each, were attributed to H-2', H-6' and H3', H-5' respectively of a para-disubstituted ring $\mathrm{B}$. The UV absorption maxima of 1 in $\mathrm{MeOH}$ at $275 \mathrm{~nm}$ (band II) and $336 \mathrm{~nm}$ (band I) are typical of flavonoids as explained by Mark- 
ham (1981). The addition of $\mathrm{NaOH}$ showed a stable spectrum which did not have any effect on band II but shifted band I from 336 to 390 $\mathrm{nm}$ with an additional band at $325 \mathrm{~nm}$. The resultant $54 \mathrm{~nm}$ bathochromic shift in band $\mathrm{I}$, coupled with increased intensity indicated a free hydroxyl group at C-4' whereas a free C-7$\mathrm{OH}$ was indicated by the presence of the new band at $325 \mathrm{~nm}$. A second bathochromic shift of $14 \mathrm{~nm}$ in band $\mathrm{I}$ in the $\mathrm{AlCl}_{3} / \mathrm{HCl}$ spectrum coupled with a $\mathrm{CDCl}_{3} / \mathrm{CD}_{3} \mathrm{OD}$ exchangeable downfield signal at $\delta_{\mathrm{H}} 13.05$ in the ${ }^{1} \mathrm{H}-\mathrm{NMR}$ spectrum supported the presence of a chelated hydroxyl group at C-5 and the absence of ortho -dihydroxyl groups. Broad absorption bands at 3411 and $3334 \mathrm{~cm}^{-1}$ in the IR spectrum of 1 were attributed to the hydroxyl groups while a band at $1654 \mathrm{~cm}^{-1}$ was assigned to the $\alpha, \beta-$ unsaturated carbonyl functional group.<smiles>COc1c(O)cc2oc(-c3ccc(O)cc3)cc(=O)c2c1O</smiles>

Fig. 1: Structure of Hispidulin (1)

A sharp three-proton singlet at $\delta_{\mathrm{H}} 3.91$ was ascribed to a methoxy group at C-6 as it showed ${ }^{3} J$ correlation with this carbon at $\delta_{\mathrm{C}}$ 131.5 in its HMBC spectrum. With the aid of the HSQC and HMBC, a doublet-like signal resonating between $\delta_{\mathrm{H}} 6.75$ and $\delta_{\mathrm{H}} 6.55$ in the ${ }^{1} \mathrm{H}-\mathrm{NMR}$ was found to be two overlapping singlets at $\delta_{\mathrm{H}} 6.65$ and $\delta_{\mathrm{H}} 6.63$. These were assigned to the vinyl proton alpha to the carbonyl, $\mathrm{H}-3$ and the aromatic proton $\mathrm{H}-8$ on ring $\mathrm{A}$ respectively. The HMBC spectrum showed cross peaks between H-2' $\left(\delta_{\mathrm{H}} 7.82\right), \mathrm{C}-1$ ' $\left(\delta_{\mathrm{C}}\right.$ $122.0)$ and $\mathrm{C}-4$ ' $\left(\delta_{\mathrm{C}} 161.2\right)$. There were also correlations between $\mathrm{H}-3$ ' $\left(\delta_{\mathrm{H}} 6.94\right)$ and $\mathrm{C}$ 1 ' $\left(\delta_{\mathrm{C}} 122.0\right)$ and C-4' $\left(\delta_{\mathrm{C}} 161.2\right)$ as well as H-8 (6.63) and C-6 $\left(\delta_{\mathrm{C}} 131.5\right)$ as demonstrated in Figure 2.

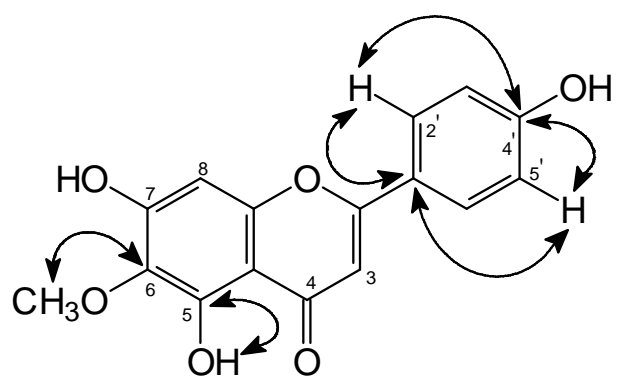

Fig. 2: HMBC in 1 indicated by doubleheaded arrow

The spectroscopic data identified 1 as the known 4',5,7-trihydroxy-6-methoxyflavone which is trivially referred to as hispidulin and has been previously isolated from a variety of plant species including Millingtonia hortensis L. (Chulasiri et al., 1992 and Hase et al., 1995), Salvia plebeia R. Br. (Gu et al., 2001), Salvia officinalis (Kavvadias et al., 2003) and Artemisia species (Tan et al., 1999). The spectral data of 1 were in accordance with published results (Hase et al., 1995).

Although some flavonoids such as hymenoxin (5,7-dihydroxy-3,4,6,8-tetramethoxyflavone), apigenin (5,7,4'-trihydroxyflavone), acacetin (5,7-dihydroxy-4'-methoxyflavone), luteolin (5,7,3',4'-tetrahydroxyflavone), scutellarein (4',5,6,7,-tetrahydroxyflavone), scutellarin (scutellarein-7- $\beta$-D-glucuronide) and sorbifolin (scutellarein-7-methylether) have been isolated from $S$. dulcis, this is the first report of the isolation of hispidulin from the plant (Technical Data Report for Vassourinha).

Compound 2 was obtained as white granules with a melting point of $251-252{ }^{\circ} \mathrm{C}$. The ${ }^{1} \mathrm{H}$ and ${ }^{13} \mathrm{C}-\mathrm{NMR}$ data of 2 compared well with that of the steroidal glycoside, $\beta$-sitosterol- $\beta$-Dglucoside (Flamini et al., 2001). The presence of the sugar moiety was corroborated by signals occurring between $\delta_{\mathrm{H}} 3.69$ and $\delta_{\mathrm{H}} 4.40$ and $\delta_{\mathrm{C}}$ 71.3 and $\delta_{\mathrm{C}} 102.1$ in the ${ }^{1} \mathrm{H}-\mathrm{NMR}$ and ${ }^{13} \mathrm{C}$ NMR spectra respectively.

The signal due to $\mathrm{C}-3$ occurred at $\delta_{\mathrm{C}} 78.3$ while H-3 appeared as a multiplet of nine lines at $\delta_{\mathrm{H}}$ 
Table 1: Comparison of ${ }^{1} \mathrm{H}$ - and ${ }^{13} \mathrm{C}$ - NMR data of 1 with literature

\begin{tabular}{|c|c|c|c|c|}
\hline \multicolumn{3}{|c|}{ Present work } & \multicolumn{2}{|c|}{ literature values } \\
\hline $\mathrm{C}-$ & $\delta_{\mathrm{C} / \mathrm{ppm}}$ & $\delta_{\mathrm{H} / \mathrm{ppm}}$ & $\boldsymbol{\delta}_{\mathrm{C} / \mathrm{ppm}}$ & $\delta_{\mathrm{H} / \mathrm{ppm}}$ \\
\hline 2 & $164.4, \mathrm{~s}$ & - & 163.8 & - \\
\hline 3 & $104.2, \mathrm{~d}$ & $6.65, \mathrm{~s}$ & 104.0 & 6.75 \\
\hline 4 & $182.6, \mathrm{~s}$ & - & 182.1 & - \\
\hline 5 & $153.3, \mathrm{~s}$ & $13.05, \mathrm{~s}$ & $152.8, \mathrm{~s}$ & $13.05, \mathrm{~s}$ \\
\hline 6 & $131.5, \mathrm{~s}$ & - & 131.4 & - \\
\hline 7 & $157.2, \mathrm{~s}$ & - & 157.3 & - \\
\hline 8 & $94.2, \mathrm{~d}$ & $6.63, \mathrm{~s}$ & 94.2 & $6.57, \mathrm{~s}$ \\
\hline 9 & $152.6, \mathrm{~s}$ & - & 152.4 & - \\
\hline 10 & $102.7, \mathrm{~s}$ & - & 102.3 & - \\
\hline $1^{\prime}$ & $122.0, \mathrm{~s}$ & - & 121.2 & - \\
\hline $2^{\prime}, 6^{\prime}$ & 128.1, d & $7.82, \mathrm{~d}, 9.0 \mathrm{~Hz}$ & 128.4 & $7.9, \mathrm{~d}, 8.8 \mathrm{~Hz}$ \\
\hline 3', 5 & $115.8, \mathrm{~d}$ & $6.94, \mathrm{~d}, 9.0 \mathrm{~Hz}$ & 115.9 & $6.9, \mathrm{~d}, 8.8 \mathrm{~Hz}$ \\
\hline $4^{\prime}$ & $161.2, \mathrm{~s}$ & - & 161.2 & - \\
\hline$-\mathrm{OCH}_{3}$ & $60.0, \mathrm{q}$ & $3.91, \mathrm{~s}$ & 59.9 & $3.73, \mathrm{~s}$ \\
\hline
\end{tabular}

Fig. 3: $\quad$ Structure of $\beta$-sitosterol- $\beta$-D-glucoside (2)

3.60 due to splitting by neighbouring protons $\mathrm{H}$ -2 and $\mathrm{H}-4$. Both values are slightly down field compared to those of $\mathrm{C}-3$ and $\mathrm{H}-3$ in $\beta$ sitosterol which occur approximately at $\delta_{\mathrm{C}} 71.8$ and $\delta_{\mathrm{H}} 3.52$ respectively. The greater deshielding effect of the acetal group in the glucoside as opposed to an oxygen atom in the aglycone may account for the observed difference. These findings confirm the presence of the sugar moiety at C-3.

\section{Anti-HIV Test}

Reported biological activities attributed to hispidulin include antimutagenicity (Chulasiri et al., 1992), hepato-toxicity (Ferrandiz et al., 1994), antioxidant activity (Gu et al., 2001), positive allosteric properties and anticonvulsant activity (Kavvadias et al., 2003, 2004) and antifungal activity (Tan et al., 1999). Hispidulin has also been found to inhibit the aggregation of human platelets by increasing cAMP levels

10 Journal of Science and Technology, Vol. 29, No. 2, Aug., 2009 
<smiles>[R6]c1cc(-c2oc3cc(O)cc(O)c3c(=O)c2O[Na])cc(Br)c1O</smiles>

$\mathrm{R}_{1}=\mathrm{OH} ; \mathrm{R}_{2}=\mathrm{H}:$ quercetin (3)

$\mathrm{R}_{1}=\mathrm{OH} ; \mathrm{R}_{2}=\mathrm{OH}:$ myricetin (4)<smiles>[R6]c1ccc(-c2cc(=O)c3c(O)c([R])c(O)cc3o2)cc1</smiles>

$\mathrm{R}_{1}=\mathrm{OH} ; \mathrm{R}_{2}=\mathrm{H}:$ baicelein (5)

$\mathrm{R}_{1}=\mathrm{OH} ; \mathrm{R}_{2}=\mathrm{OH}:$ scutellarein (6)

$\mathrm{R}_{1}=\mathrm{OCH}_{3} ; \mathrm{R}_{2}=\mathrm{OH}$ : hispidulin (1)
(Bourdillat et al., 1988). However, its potential as an anti-HIV agent is yet to be reported. A variety of flavonoids have been shown to demonstrate anti-HIV activity, particularly the inhibition of different stages in the replication cycle of HIV (Spedding et al., 1989, De Clercq, 2001, Vlietinck et al., 1998). Among these are quercetin (3), myricetin (4), baicalein (5) and scutellarein (6), the latter being previously isolated from S. dulcis (Technical Data Report for Vassourinha). The structural features that were reported to be crucial for reverse-transcriptase (RT)-inhibition were the double bond between $\mathrm{C}-2$ and $\mathrm{C}-3$ of the flavonoid pyrone ring, and the three hydroxy groups at C-5, C- 6 and C-7.

The absence of $6-\mathrm{OH}$ in 3 and 4 required at least three additional hydroxy groups at $\mathrm{C}-3, \mathrm{C}-$ $3^{\prime}$ and $\mathrm{C}-4$ ' in 3 and C-3, C-3', C-4' and C-5' in 4 to bring about RT-inhibition. The structural difference between scutellarein (6) and hispidulin (1) is at $\mathrm{C}-6$ where $6-\mathrm{OH}$ in 6 has been substituted with $6-\mathrm{OCH}_{3}$ in 1 . In spite of this difference, C-6 is still oxygenated and 1 may be considered as possessing the requisite structural features to be a potential RTinhibitor. The present investigation therefore sought to verify this claim but unfortunately, due to unavailability of the RT-inhibition assay at the time of the experimental procedure, a different method, involving a tetrazolium-based colorimetric selective assay was employed as an initial toxicity assay (Ayisi et al., 1991).

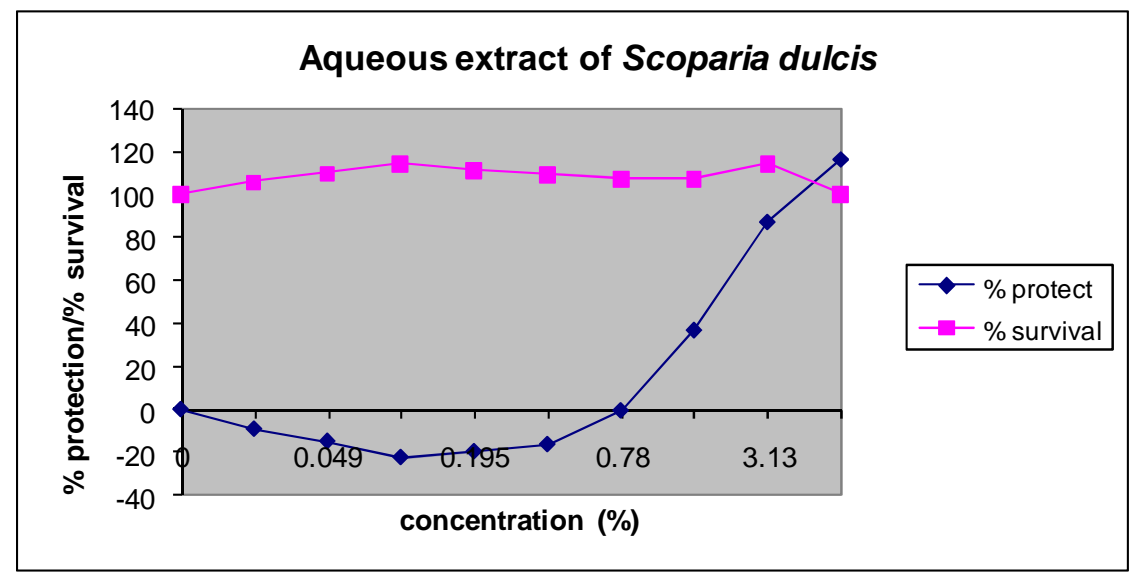

Fig. 4: Graph of ratio of \% protection to \% survival against conc. of crude aqueous extract 
Table 2: Antiviral indices of hispidulin and crude aqueous extract of $S$. dulcis

\begin{tabular}{lccc}
\hline Sample & $\mathrm{EC}_{50}(\%)$ & $\mathrm{CC}_{50}(\%)$ & $\mathrm{CC}_{50} / \mathrm{EC}_{50}$ \\
\hline Hispidulin & 13.75 & 13.75 & 1 \\
Aqueous extract & 2.06 & $>6.25$ & 4.7 \\
\hline
\end{tabular}

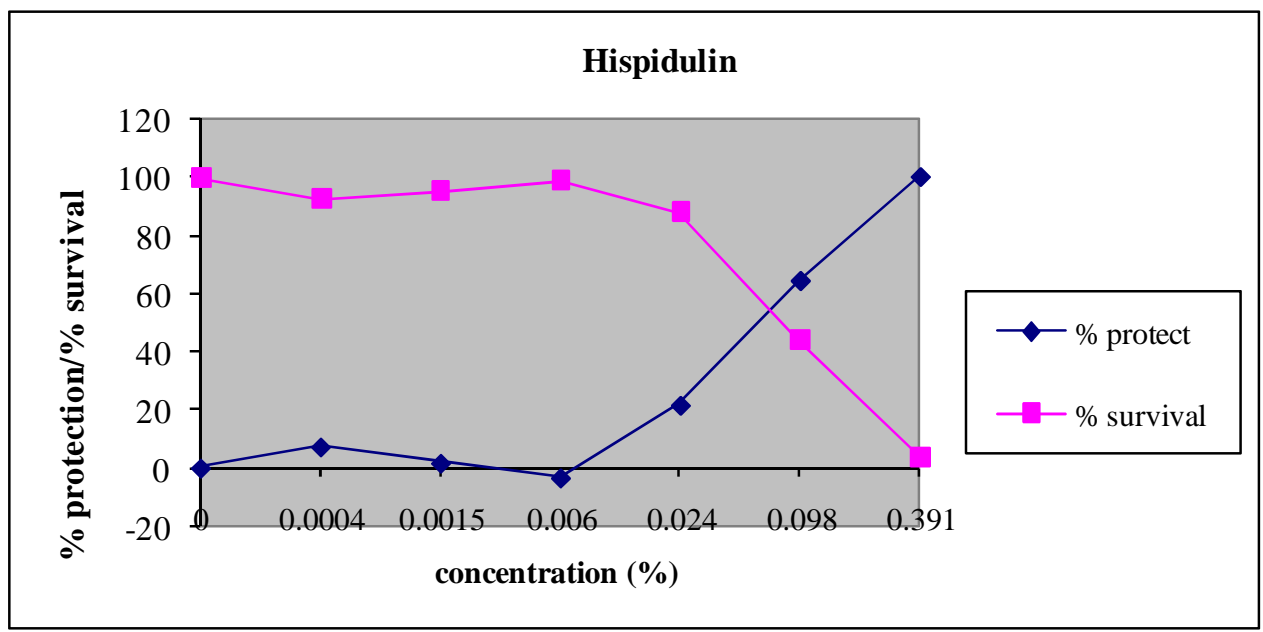

Fig. 5: Graph of ratio of $\%$ protection to $\%$ survival against conc. of hispidulin

A trial determination was carried out on the crude aqueous extract of the plant, which showed a remarkably high concentrationdependent inhibition of HIV-1/IIIB in MT-4 cells. Complete inhibition (100\% protection) was attained without toxicity to the cells (Fig. 4), with a calculated antiviral index of 4.7 (Table 2).

In the case of hispidulin however, the results (Fig. 5), indicated that the concentration of hispidulin required to achieve $50 \%$ protection $(13.75 \%)$ in MT-4 cells against HIV-1/IIIB, was the same as that required to cause $50 \%$ toxicity, giving a calculated antiviral index of 1 (Table 2).

Although inhibition was elicited at a concentration that also happened to be toxic to the cells, these results do not imply that hispidulin may not possess any type of anti-HIV property, particularly RT-inhibition, which is common with flavonoids (Spedding et al., 1989, De Clercq,
2001, Vlietinck et al., 1998). Efforts are therefore being made to have access to RTinhibition assay which was not readily available at the time of testing, to determine the RTinhibitory potential or otherwise of hispidulin. Then, can conclusive statements be made about the anti-HIV potential of hispidulin.

The positive results obtained for the crude extract could be due to the presence of other constituents, for example, betulinic acid, 6methoxybenzoxazolinone (isolated in the present study) and scutallerin which have been reported to have anti-HIV properties including HIV replication inhibition and virus-cell fusion among others (De Clercq, 2001, Evers et al., 1990, Fulda et al., 1999 and 2000, Kanamoto et al., 2001, Noda et al., 1997, Soler et al., 1996, Spedding et al., 1989, Zhang et al., 2005).

\section{ACKNOWLEDGEMENTS}

Thanks are due to Professor Nana Ayisi of the Noguchi Memorial Institute for Medical Re- 
search (NMIMR) University of Ghana, Legon for his contribution to the Anti-HIV bioassay and the University of Ghana for University Post -Graduate Fellowship to Dr. Mary Anti Chama.

\section{REFERENCES}

Ageta H., Arai Y., Suzuki H., Kiyotani T. and Kitabayashi M., (1995). "NMR Spectra of Triterpenoids. III. Oleanenes and Migrated Oleanenes". Chemical and Pharmaceutical Bulletin, 43(2): 198-203.

Ahmed M. and Jakupovic J. (1990). "Diterpenoids from Scoparia dulcis". Phytochemistry 29(9): 3035-3037.

Ahmed M., Shikha H. A., Sadhu S. K., Rahman M. T. and Datta B. K. (2001). "Analgesic, diuretic and anti-inflammatory principle from Scoparia dulcis". Pharmazie, 56(8): 657-660.

Ahsan M., Islam S. K. N., Gray A. I. and Stimson W. H. (2003). "Cytotoxic diterpenes from Scoparia dulcis". Journal of Natural Products, 66: 958-961.

Ayisi, N.K., Gupta, S. V. and Qualtiere, L.F. (1991). "Modified tetrazolium-based colorimetric method for determining the activities of anti-HIV compounds". J. Virol Methods, 33: 335-344.

Babincova, M. and Sourivong, P. (2001). "Free radical scavenging activity of Scoparia dulcis extract." Journal of Medicinal Food, 4(3): 179-181.

Bourdillat B., Delautier D., Labat C., Benveniste J., Potier P. and Brink C. (1988). "Hispidulin, a natural flavone, inhibits human platelet aggregation by increasing cAMP levels". Eur. J. Pharmacol., 147 (1): 1-6.

Burkill H. M. (2000). The Useful Plants of West Tropical Africa, 2 ${ }^{\text {nd }} \mathrm{Ed}, 5$, Royale Botanic Gardens, Kew: 77-79.

Chen C-M. and Chin M-T. (1976). "6methoxybenzoxazolinone and triterpenoids from the roots of Scoparia dulcis". Phytochemistry, 15: 1997-1999.
Chulasiri M., Bunyapraphatsara N. and Moongkarndi P. (1992). "Mutagenicity and antimutagenicity of hispidulin and hortensin, the flavonoids from Millingtonia hortensis L.". Environ Mol Mutagen, 20(4): 307312.

Corey E. J. and Ursprung J. J., (1956). "Isolation of Friedelan-3-One". Journal of American Chemical Society, 78: 5041.

De Clercq, E. (2001). "New developments in anti-HIV chemotherapy." Current Medicinal Chemistry 8(13): 1543-72.

De Mayo P., (1959). The Higher Terpenoids. Interscience Publishers, New York: 202215.

Evers, M., Poujade, C., Soler, F., Ribeill, Y., James, C., Lelievre, Y., Gueguen, J-C, Reisdorf, D., Morize, I., Pauwels, R., De Clercq, E., Hénin, Y., Bosseau, A., Mayaux, J-F., Le Pecq, J-B. and Dereu N. (1996). "Betulinic acid derivatives: a new class of human immunodeficiency virus type 1specific inhibitors with a new mode of action". Journal of Medicinal Chemistry, 39(5): 1056-1068.

Ferrandiz M. L., Bustos G., Paya M., Gunasegaran R. and Alcaraz M. J. (1994). "Hispidulin protection against hepatotoxicity induced by bromobenzene in mice". Life Sci, 55(8): 145-150.

Flamini G., Antognoli E. and Morelli I., (2001). Two flavonoids and other compounds from the aerial parts of Centaurea bracteata from Italy. Phytochemistry, 57, 559-564.

Friere, S., Emim, J., Lapa, A., Souccar, C. and Torres, L. (1993). "Analgesic and antiinflammatory properties of Scoparia dulcis L. extracts and glutinol in rodents". Phytotherapy Research 7(6): 408-414.

Fulda S. and Debatin K-M. (2000). "Betulinic acid induces apoptosis through a direct effect on mitochondria in neuroectodermal tumors". Medical and Pediatric Oncology, 35(6): 616-618. 
Fulda S., Jeremias I., Steiner H. H., Pietsch T. and Debatin K-M. (1999). "Betulinic acid: A new cytotoxic agent against malignant brain-tumor cells". International Journal of Cancer, 82(3): 435-441.

Gu L. and Weng X. (2001). "Antioxidant activity and components of Salvia plebeia $\mathrm{R}$. Br.”. Food Chemistry, 73(30): 299-305.

Hase T., Ohtani K., Kasai R., Yamasaki K. and Picheasoonthon C. (1995). "Revised structure for hortensin, a flavone from Millingtonia hortensis". Phytochemistry, 40(1): 287-290.

Hayashi K., Hayashi T. and Morita N. (1991). "Cytotoxic and antitumor activity of scopadulcic acid from Scoparia dulcis L.”. 6(1): 6-9.

Hayashi K., Niwayama S., Hayashi T., Nago R., Ochiai H. and Morita N. (1988). "In vitro and in vivo antiviral activity of scopadulcic acid B from Scoparia dulcis, Scrophulariaceae, against herpes simplex virus type 1". Antiviral Research, 9: 345-354.

Hayashi T., Asano S., Mizutani M., Takeguchi N., Kojima T., Okamura K. and Morita N. (1991). "Scopadulciol - An inhibitor of gastric $\mathrm{H}+, \mathrm{K}+-$ Atpase from Scoparia dulcis, and its structural activity relationships". Journal of Natural Products, 54(3): 802-809.

Hayashi T., Kawasaki M., Arisawa M., Shimizu M., Horie S., Ueno H., Syogawa, H., Suzuki S., Yoshizaki M., Morita N., Tezuka Y., Kikuchi T., Berganza, L. H., Ferro E. and Basualdo I. (1987). "Structure of scoparic acid A, a new labdane-type diterpenoid from a Paraguayan crude drug 'typychá kuratū'(Scoparia dulcis L.)'. Chemical and Pharmaceutical Bulletin, 35: 3963-3966.

Hayashi T., Kawasaki M., Miwa Y., Taga T. and Morita N. (1990). "Antiviral agent of plant origin. III. Scopadulin, a novel tetracyclic diterpene from Scoparia dulcis L". Chemical and Pharmaceutical Bulletin, 38 (4): 945-947.
Hayashi T., Kishi M., Kawasaki M., Arisawa M., Shimizu M., Suzuki S., Yoshizaki M., Morita N., Tezuka Y., Kikuchi T., Berganza, L. H., Ferro E. and Basualdo I. (1987b). "Scopadulcic acid- A and -B, new diterpenoids with a novel skeleton, from a Paraguayan crude drug 'typychá kuratū'(Scoparia dulcis L.)". Tetrahedron Letters, 28: 3693-3696.

Hayashi T., Okamura K., Kawasaki M. and Morita N. (1991). "Two chemotypes of Scoparia dulcis in Paraguay". Phytochemistry, 30(11): 3617-3620.

Hayashi T., Okamura K., Kawasaki M. and Morita N. (1993). "Production of diterpenoids by cultured cells from two chemotypes of Scoparia dulcis". Phytochemistry, 33(2): 353-356.

Hayashi T., Uchida K., Hayashi K., Niwayama S. and Morita N. (1988). "A cytotoxic flavone from Scoparia dulcis L.". Chemical and Pharmaceutical Bulletin, 36(12): 4849-4851.

Kanamoto T., Kashiwada Y., Kanbara K., Gotoh. K., Yoshimori M., Goto T., Sano K. and Nakashima H. (2001). "Anti-human immunodeficiency virus activity of YKFH312 (a betulinic acid derivative), a novel compound blocking viral maturation". Antimicrobial Agents and Chemotherapy, 45(4): 1225-1230.

Kavvadias D., Monschein V., Sand P., Reiderer P and Schreier P. (2003). "Constituent of Sage (Salvia officinalis) with in vitro affinity to human brain benzodiazepine receptor”. Planta Medica, 69(2): 113-117.

Kavvadias D., Sand P., Youdim K. A., Qaiser M. Z., Rice-Evans C., Baur R., Sigel E., Rausch W-D., Reiderer P. and Schreier P. (2004). "The flavone hispidulin, a benzodiapine receptor ligand with positive allosteric properties, traverses the blood-brain barrier and exhibits anticonvulsive effects". British Journal of Pharmacology, 142: $811-820$

14 Journal of Science and Technology, Vol. 29, No. 2, Aug., 2009 
Latha, M., Ramkumar K. M., Pari L., Damodaran, P. N., Rajeshkannan V. and Suresh T. (2006). "Phytochemical and antimicrobial study of an antidiabetic plant: Scoparia dulcis". Journal of Meicinal Food, 9(3): 391-394.

Mahato S. B., Das M.C. and Sahu N. P. (1981). "Triterpenoids of Scoparia dulcis". Phytochemistry, 20: 171-173.

Markham K. R. (1981). Techniques of flavonoid identification; Biological Techniques Series. Academic Press, England, 36-51.

Nishino H., Arisawa M., Satomi Y. and Iwashima A. (1993). "Antitumor-promoting activity of scopadulcic acid B, isolated from the medicinal plant Scoparia dulcis L.”. Oncology, 50(2): 100 -103.

Noda Y., Kaiya T., Kohda K., Kawazoe Y. (1997). "Enhanced cytotoxicity of some triterpenes toward leukemia 11210 cells cultured in low $\mathrm{pH}$ media: possibility of a new mode of cell killing". Chemical and Pharmaceutical Bulletin, 45: 1665-1670.

Phan, M. G., Phan, T. S., Matsunami, K. and Otsuka H. (2006). "Chemical and biological evaluation on scopadulane-type diterpenoids from Scoparia dulcis of Vietnamese origin". Chemical and Pharmaceutical Bulletin, 54 (4): 546-549.

Riel M. A., Kyle D. E. and Milhous W. K. (2002). "Efficacy of Scopadulcic acid A against Plasmodium falciparum in vitro". Journal of Natural Products, 65(4): 614615.

Spedding, G., Ratty, A. and Middleton Jr, E. (1989). "Inhibition of reverse transcriptases by flavonoids." Antiviral Research, 12 (2): 99-110.
Sitthithaworn W., Kojima N., Viroonchatapan E., Suh D-Y., Iwanami N., Hayashi T., Noji M., Saito K. Niwa Y. and Sankawa U. (2001). "Geranylgeranyl diphosphate synthase from Scoparia dulcis and Croton sublyratus. Plastid localization and conversion to farnesyl diphosphate synthase by mutagenesis". Chemical and Pharmaceutical Bulletin, 49(2): 197-202.

Soler, F., Poujade, C., Evers, M., Carry, J-C, Hénin, Y., Bosseau, A., Huet, T., Pauwels, R., De Clercq, E., Mayaux, J-F., Le Pecq, J -B. and Dereu N. (1996). "Betulinic acid derivatives: a new class of specific inhibitors of human immunodeficiency virus type 1 entry." Journal of Medicinal Chemistry, 39(5): 1069-83.

Tan R. X., Lu H., Wofender J. L., Yu T. T., Zheng W. F., Yang L., Gafner S. and Hostettmann K, (1999). "Mono- and Sesquiterpenes and antifungal constituents from Artemisia species". Planta Medica, 65(1): 64-67.

Taylor, L. (2005). The Healing power of the rainforest herbs. Square One Publishers Inc. Carson City, NV.

Technical Data Report for Vassourinha (Scoparia dulcis). Sage Press, Austin: Texas. 2002. (www.rain-tree.com)

Vlietinck, A. J., De Bruyne, T., Apers, S. and Pieters, L. A. (1998). "Plant-derived leading compounds for chemotherapy of human immunodeficiency virus (HIV) infection." Planta Medica, 64(2): 97-109.

Zhang G. H., Wang Q., Chen J. J. (2005). "The anti-HIV-1 effect of scutellarin". Biochem. Biophys. Res. Commun., 334(3): 812-816. 